\title{
Merger of Betula tatewakiana (Betulaceae) from northern Japan with northeast Asian B. ovalifolia based on ploidy level
}

\author{
Yuki Shiotani', Tomoko Fukuda², Elena A. Marchuk ${ }^{3}$, Ekaterina A. Petrunenko³, \\ Pavel V. Krestov ${ }^{3}$, Svetlana N. Bondarchuk ${ }^{4}$, Yoko Nishikawa ${ }^{5}$, \\ Takashi Shimamura $^{5}$, Yoshiyasu Fujimura ${ }^{6}$, Koh Nakamura ${ }^{7}$
}

I Division of Biosphere Science, Graduate School of Environment Science, Hokkaido University, Sapporo 0600810, Japan 2 College of Liberal Arts and Sciences, Mie University, Tsu 514-8507, Japan 3 Botanical GardenInstitute, Far Eastern Branch of the Russian Academy of Sciences, Makovskii Str. 142, Vladivostok, 690024, Russia 4 Sikhote-Alin State Nature Biosphere Reserve, Ministry of Nature Resources and Environment, Terney, 692150, Russia 5 Institute of Environmental Sciences, Hokkaido Research Organization, Sapporo 060-0819, Japan 6 Research \& Development Center, Nippon Koei Co. Ltd., Tsukuba 300-1259, Japan 7 Botanic Garden, Field Science Center for Northern Biosphere, Hokkaido University, Sapporo 060-0003, Japan

Corresponding author: Koh Nakamura (kohnakamur@gmail.com)

Academic editor:H.Schaefer | Received 12September 2020 | Accepted 20 November $2020 \mid$ Published 23 December 2020

Citation: Shiotani Y, Fukuda T, Marchuk EA, Petrunenko EA, Krestov PV, Bondarchuk SN, Nishikawa Y, Shimamura T, Fujimura Y, Nakamura K (2020) Merger of Betula tatewakiana (Betulaceae) from northern Japan with northeast Asian B. ovalifolia based on ploidy level. PhytoKeys 170: 83-91. https://doi.org/10.3897/phytokeys.170.58585

\begin{abstract}
It has been controversial whether Betula tatewakiana, a dwarf birch distributed in Hokkaido of northern Japan, is an endemic species or a synonym of $B$. ovalifolia broadly distributed in northeast Asia. The endemic hypothesis is based on the idea that $B$. tatewakiana is diploid while $B$. ovalifolia is tetraploid and that they are separated based on the ploidy level; however, no chromosome data have actually been published before. Resolving the taxonomic problem is crucial also in judging the conservation priority of $B$. tatewakiana in a global perspective. Our chromosome observation revealed that $B$. tatewakiana is tetraploid as well as B. ovalifolia. We also conducted morphological observations and clarified that $B$. tatewakiana is morphologically identical to $B$. ovalifolia in white hairs and dense resinous glands respectively on adaxial and abaxial leaf surfaces, in which they differ from closely related species in the same section Fruticosae. We conclude that the hypothesis that B. tatewakiana is a Hokkaido endemic based on the ploidy level is not supported and that B. tatewakiana should be merged with B. ovalifolia.
\end{abstract}

Copyright Yuki Shiotani et al. This is an open access article distributed under the terms of the Creative Commons Attribution License (CC BY 4.0), which permits unrestricted use, distribution, and reproduction in any medium, provided the original author and source are credited. 


\section{Keywords}

Betula, chromosome number, conservation, dwarf birch, endangered species, Hokkaido, Japan, polyploidy, Russian Far East, wetland

\section{Introduction}

Betula ovalifolia Rupr. is a dwarf birch found in wetlands (Gray 1996; Li and Skvortsov 1999). It grows only up to ca. $2 \mathrm{~m}$ tall (Li and Skvortsov 1999) and reproduces not only by seeds but also asexually by branching near ground level (Tabata 1966). This species is widely distributed in northeast Asia, i.e., Russian Far East (southern Khabarovsky Krai, Primorsky Krai, Amur Oblast, Jewish Autonomous Oblast), northeast China (Heilongjiang, Changbai Shan, Nei Mongol), North Korea, and northern Japan (Hokkaido) (Fig. 1; Gray 1996; Li and Skvortsov 1999). However, the taxonomic treatment of $B$. ovalifolia from Japan, and thereby its occurrence in Japan, has been controversial. In the first report from Japan, it was treated as an endemic species of Hokkaido and named $B$. tatewakiana M.Ohki \& S.Watan. (Watanabe and Ohki 1959). Afterward, it had been treated as a variety of B. humilis Schrank (Murata 1978). Soon after that, Hara (1979) claimed that this species is identical to $B$. ovalifolia, but no data were presented. Since then, although this opinion is widely accepted in pictorial books and floras in Japan (Murata 1979; Ito 1981; Ohba 2006; Takahashi 2015), the idea to support B. tatewakiana was claimed again (Watanabe 1995) and the taxonomic problem still remains (Takahashi 2013; Takahashi et al. 2013; Nemoto 2016). Here, we tentatively use the name $B$. tatewakiana and will later discuss its taxonomy and proper name based on our results.

The taxonomic problem of $B$. tatewakiana and B. ovalifolia stems from the confusion in their ploidy level. Watanabe (1995) claimed that B. tatewakiana is diploid while $B$. ovalifolia is tetraploid and he recognized $B$. tatewakiana as the Japanese endemic restricted to Hokkaido. This idea, however, was originally reported in a conference abstract without images of the chromosomes (Watanabe and Somego 1991) and has never been published, but repeatedly mentioned in the following studies (Nemoto 2016). On the other hand, Nagamitsu et al. (2004) did not separate the two species and treated B. ovalifolia from Hokkaido as a tetraploid species based on Probatova and Sokolovskaya (1995, in Russian), who actually did not report the chromosome number of B. ovalifolia but of a hybrid between B. ovalifolia and B. exilis. A flow cytometric study of the genome size evolution in the genus Betula suggested that $B$. ovalifolia from the Asian continent is tetraploid (Wang et al. 2016). Ashburner and McAllister (2016) treated B. tatewakiana and B. ovalifolia as synonyms of B. fruticosa Pall. and reported the chromosome number $2 n=56$ for $B$. fruticosa. According to the author (McAllister, personal communication), the chromosome observations were made with plants grown from seeds collected in Sarabetsu mire and Olga in Russian Far East. However, the materials were not mentioned in Ashburner and McAllister (2016) and one cannot be certain that the chromosome number applies to B. tatewakiana and B. ovalifolia. 

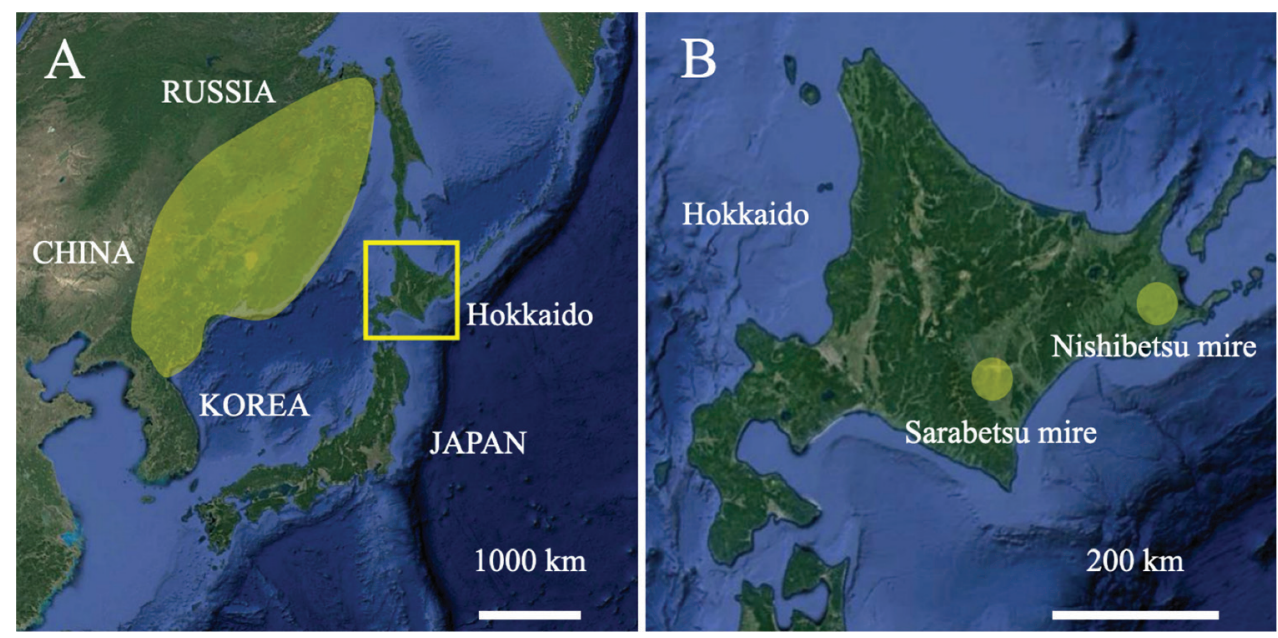

Figure I. Species distribution ranges of Betula ovalifolia (A) and B. tatewakiana (B). Map data 2020 (C) Google.

Thus, no published information exists about the ploidy level of B. tatewakiana and $B$. ovalifolia based on chromosome observations.

In this study, to resolve the taxonomic problem of B. tatewakiana, we focused on the confusion about the ploidy level, because this is the cause of the taxonomic controversy. We conducted chromosome observation and determined the ploidy level. We also conducted morphological observations of B. tatewakiana. Regarding B. ovalifolia, there are two closely related species in the same section Fruticosae, i.e., B. humilis Schrank and B. fruticosa Pall. Betula ovalifolia is distinguished from the two species by white hairs on the adaxial leaf surface (vs. glabrous in B. humilis and B. fruticosa) and by densely resinous glands on the abaxial leaf surface (vs. lack of glands in B. humilis) (Kuzeneva 1985, Li and Skvortsov 1999). In previous studies, which did not accept $B$. tatewakiana, these traits have not been well compared between B. tatewakiana and $B$. ovalifolia. Resolving the taxonomic problem and assessing the endemic status of B. tatewakiana would also help planning its conservation. Betula tatewakiana is found only in two localities in Japan, i.e., Sarabetsu and Nishibetsu mires in eastern Hokkaido (Fig. 1B). As a result of the exploitation of the mires, remaining habitats are only 3 and 16 ha in Sarabetsu and Nishibetsu mires, respectively (Takahashi 2013). Open ditches excavated inside and outside the mires are increasingly drying the habitats of B. tatewakiana and thereby it is red-listed at national and prefectural levels (Hokkaido 2001; Ministry of the Environment, Government of Japan 2020). Whether it is endemic or not is related to its conservation priority in a global perspective; on the other hand, if it is the same species as B. ovalifolia broadly distributed in northeast Asia, effective conservation should be planned considering genetic connectivity with conspecific populations abroad. This study is expected to provide basic information essential for the conservation of the species. 


\section{Materials and methods}

\section{Determination of ploidy level}

We collected seeds of $B$. tatewakiana from six and five individuals from Sarabetsu and Nishibetsu mires in Hokkaido, Japan; seeds of B. ovalifolia were collected from one individual in Sikhote-Alin Nature Reserve in Primorsky Krai, Russian Far East (Table 1). Collected seeds were dried with silica gel and stored at $4{ }^{\circ} \mathrm{C}$. Seeds were sowed on vermiculite and germinated at $25^{\circ} \mathrm{C}$ day $/ 8{ }^{\circ} \mathrm{C}$ night condition for two weeks. After germination, root tips were collected and pretreated with $0.002 \mathrm{M}$ 8-hydroxyquinoline solution for 24 hours at $4{ }^{\circ} \mathrm{C}$ in dark condition. Next, the root tips were fixed in Farmer's solution (glacial acetic acid: 99\% ethanol $=1: 3$ ) at $4{ }^{\circ} \mathrm{C}$ in dark condition. After fixation, the root tips were macerated in $1 \mathrm{~N} \mathrm{HCl}$ for 18 minutes and stained with $1 \%$ aceto-orcein for 5 minutes and squashed on a slide. Metaphase chromosomes were observed using an optical microscope Zeiss Axio Imager A1 (Carl Zeiss, Jena, Germany), and pictured by Anyty 3R-DKMC01 (3R solution corp., Fukuda, Japan).

\section{Morphological observations}

To elucidate whether B. tatewakiana is morphologically identical to B. ovalifolia or not, we observed the key traits in the section Fruticosae: white hairs and dense resinous glands respectively on the adaxial and abaxial leaf surfaces. For B. tatewakiana, specimens examined were the holotype of $B$. tatewakiana (H. Suzuki and M. Ohki, s.n. with handwriting "Type" and collected on 18 August 1958 as cited in the protologue) in the herbarium of Hokkaido University Museum (SAPS) and our collections of 51 and 45 plants from Sarabetsu and Nishibetsu mires, that were deposited in the herbarium of Hokkaido University Botanic Garden (SAPT) (Appendix 1). For B. ovalifolia, our collections of 38 specimens from Primorsky Krai in the Russian Far East were used (SAPT, Appendix 1).

\section{Results}

\section{Ploidy level}

Somatic chromosomes at metaphase were approximately $1.0 \mu \mathrm{m}$ long in both $B$. $t a-$ tewakiana (Fig. 2A-D) and B. ovalifolia (Fig. 2E, F). The centromere positions could not be determined because of the small sizes of the chromosomes. The result of chromosome counts is summarized in Table 1. In B. tatewakiana from Sarabetsu mire, 3 individuals had 56 chromosomes (HUBG 14746 A, E, H) and 3 individuals had ca. 56 chromosomes (HUBG 14746 B, D, F). In B. tatewakiana from Nishibetsu mire, 4 individuals had 56 chromosomes (Yuki Shiotani 1, 26, 29, 30) and 1 individual had ca. 
Table I. Chromosome counts of Betula tatewakiana and B. ovalifolia.

\begin{tabular}{cccc}
\hline Taxon & Sampling site & Chromosome counts & Voucher no. \\
\hline B. tatewakiana & $42^{\circ} 37.33^{\prime} \mathrm{N}, 143^{\circ} 15.72^{\prime} \mathrm{E}$, alt. 166 m, Sarabetsu mire, & 56 & HUBG* 14746 A, E, H \\
& Sarabetsu village, Hokkaido, Japan & ca. 56 & HUBG 14746 B, D, F \\
& $43^{\circ} 23.36^{\prime} \mathrm{N}, 145^{\circ} 03.66^{\prime} \mathrm{E}$, alt. 32 m, Nishibetsu mire, & 56 & Yuki Shiotani 1, 26, 29, 30 (SAPT) \\
& Betsukai town, Hokkaido, Japan & ca. 56 & Yuki Shiotani 27 (SAPT) \\
B. ovalifolia & $44^{\circ} 57.31^{\prime} \mathrm{N}, 136^{\circ} 33.01^{\prime} \mathrm{E}$, alt. 25 m, Sikhote-Alin & 56 & Koh Nakamura 14198 (SAPT) \\
& Nature Reserve, Terney, Primorsky Krai, Russia & & \\
\hline
\end{tabular}

*HUBG: living collections of Hokkaido University Botanic Garden.
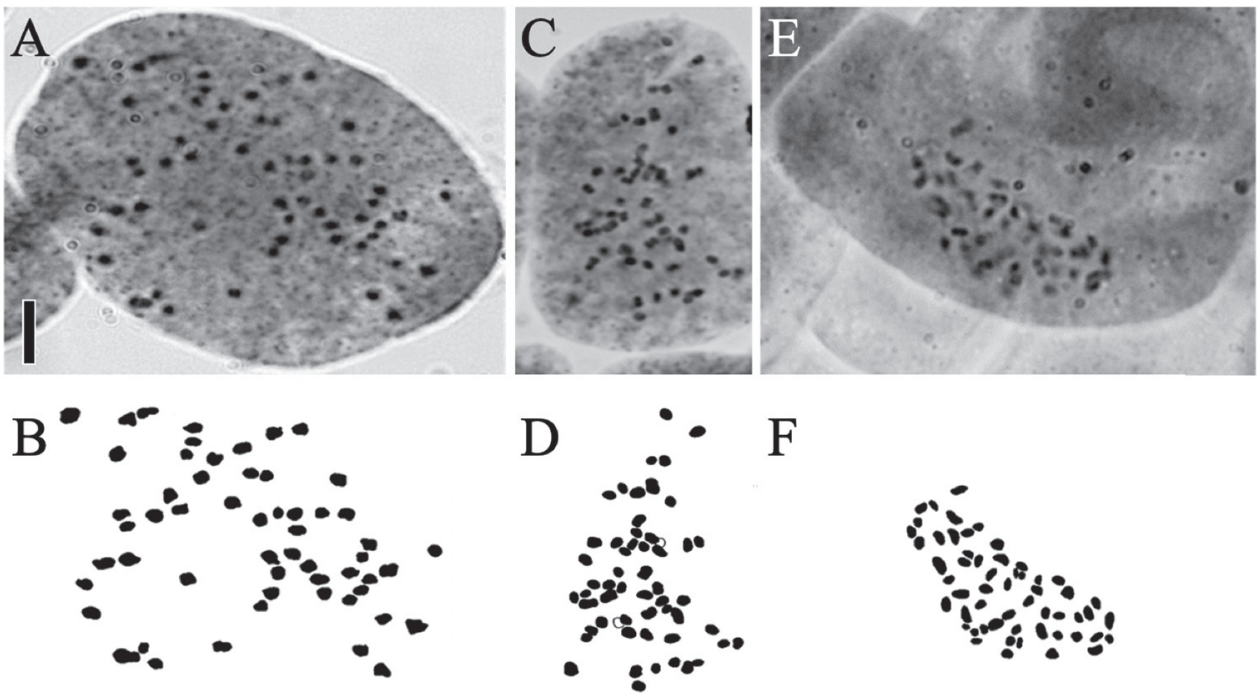

Figure 2. Somatic chromosomes at metaphase of B. tatewakiana and B. ovalifolia. Photomicrographs of B. tatewakiana from Sarabetsu mire (A, $2 n=56$ : HUBG 14746 A) and Nishibetsu mire (C, $2 n=56$ : Yuki Shiotani 29), and B. ovalifolia from Primorsky Krai (E, $2 n=56$ : Koh Nakamura 14198) are shown. $\mathbf{B}, \mathbf{D}, \mathbf{F}$ are drawings of $\mathbf{A}, \mathbf{C}, \mathbf{E}$, respectively. Scale bar: $5 \mu \mathrm{m}$.

56 chromosomes (Yuki Shiotani 27). In B. ovalifolia from Primorsky Krai, 1 individual had 56 chromosomes (Koh Nakamura 14198).

\section{Morphological traits}

The holotype of $B$. tatewakiana has white hairs and dense resinous glands respectively on the adaxial and abaxial leaf surface (Fig. 3A, B). Our collections of B. tatewakiana also have white hairs and dense resinous glands on the adaxial and abaxial leaf surface, respectively (Fig. 3C, D) and no morphological difference was recognized between the samples from Sarabetsu and Nishibetsu mires. In B. ovalifolia, our collections from Primorsky Krai have white hairs and dense resinous glands respectively on adaxial and abaxial leaf surface as well as B. tatewakiana (Fig. 3E, F). 

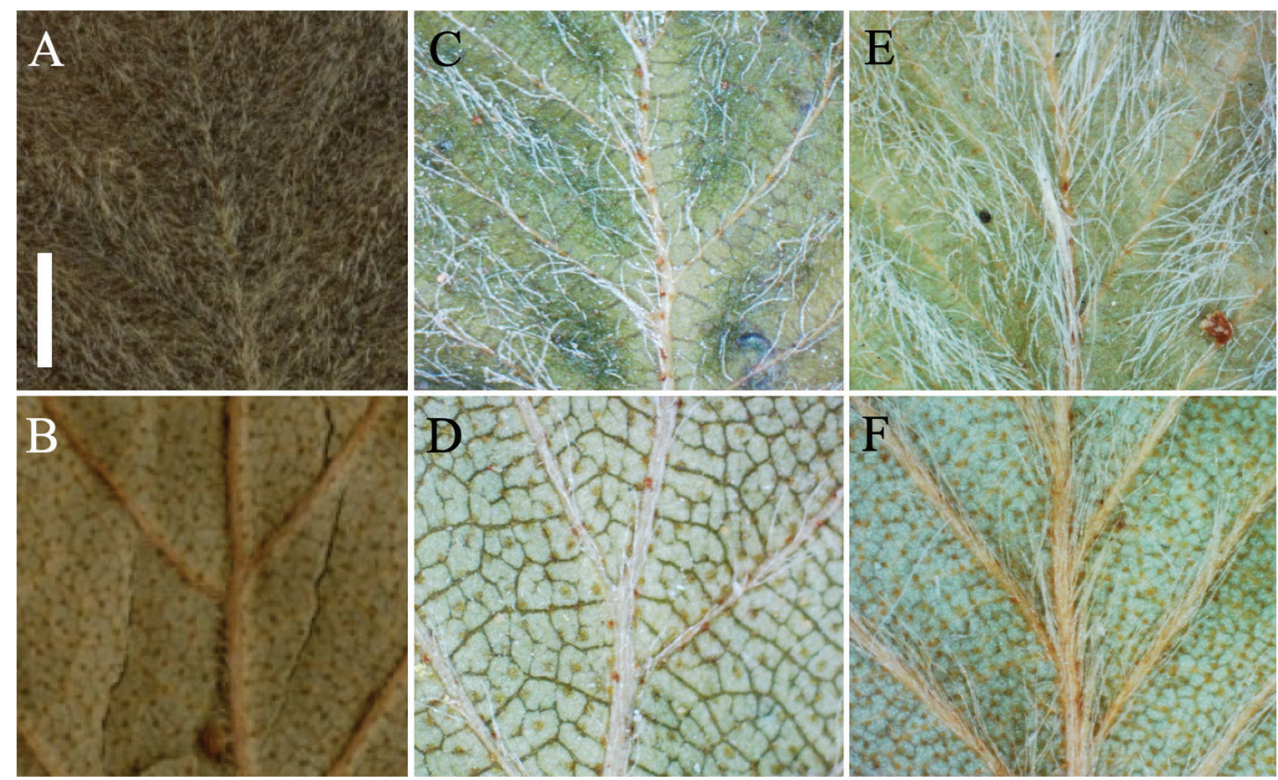

Figure 3. Leaf traits of B. tatewakiana and B. ovalifolia. White hairs on adaxial leaf surface $(\mathbf{A}, \mathbf{C}, \mathbf{E})$ and densely resinous glands on abaxial leaf surface (B, D, F) are shown for the holotype of $B$. tatewakiana (H. Suzuki and M. Ohki, s.n., A, B), B. tatewakiana of our collection (Yuki Shiotani 38, C, D), and B. ovalifolia in Russia (Koh Nakamura 14188, E, F). Scale bar: $1 \mathrm{~mm}$.

\section{Discussion}

\section{Merger of B. tatewakiana with B. ovalifolia}

In our chromosome observation, the samples of B. tatewakiana from Sarabetsu and Nishibetsu mires had $2 n=56$ (seven samples) and ca. 56 (four samples) chromosomes (Table 1). The chromosomes were too small (approximately $1.0 \mu \mathrm{m}$ long) to observe clearly and the chromosome count variation may need further verification; however, it is safe to say that $B$. tatewakiana is tetraploid because the basic chromosome number is 14 in the genus Betula (Erikkson and Jonsson 1986) and the diploid count should be $2 n=28$. Watanabe and Somego (1991) reported that B. tatewakiana is diploid, although no images of the chromosomes were presented. Thus, the possibility that there are both diploid and tetraploid in B. tatewakiana is not totally denied. However, his report was a gametophytic count and according to the author Watanabe the chromosome image was unclear (personal communication). For this reason, $B$. tatewakiana is highly likely to be tetraploid. Our chromosome count of B. ovalifolia was $2 n=56$. This is consistent with the flow cytometric study that suggested that $B$. ovalifolia from the Asian continent is tetraploid (Wang et al. 2016). Therefore, the idea to separate B. tatewakiana from B. ovalifolia based on the ploidy level (Watanabe and Somego 1991; Watanabe 1995) is not supported because both species are tetraploid. Hence, $B$. tatewakiana should be merged with B. ovalifolia. The observation of the morphological 
traits also supports the merger of B. tatewakiana with $B$. ovalifolia. The two species are morphologically identical in white hairs and dense resinous glands respectively on the adaxial and abaxial leaf surfaces, based on which they are different from closely related dwarf birch species in the same section Fruticosae.

\section{Taxonomic treatment}

Betula ovalifolia Rupr., Bull. Cl. Phys.-Math. Acad. Imp. Sci. Saint-Pétersbourg 15: 378 (1857)

EB. tatewakiana M.Ohki \& S.Watan., J. Jap. Bot. $34: 329$ (1959). Type: JAPAN, Hokkaido, Sarabetsu village: 18 August 1958, H. Suzuki and M. Ohki, s.n. (holotype, SAPS!)

Type. Russia. Khabarovsk region: Mandshuria, 25 July 1855, R. Maack, s.n. (holotype, LE 01016954!)

\section{Implications for conservation}

Betula tatewakiana is recognized as a synonym of $B$. ovalifolia as discussed above, and thereby it is not a Japanese endemic species. Hereafter, the Hokkaido populations are called B. ovalifolia. Because B. ovalifolia is broadly distributed in northeast Asia, i.e., Russian Far East, northeast China, North Korea, and northern Japan, the conservation priority of the species may not be high in a global perspective. On the other hand, the Hokkaido populations represent the only island populations disjunct from continental populations. The species had likely moved southward during glacial periods and retreated northward in warmer periods, and the Hokkaido populations are considered to be relict populations (Takahashi 2013). The Hokkaido populations can be reproductively isolated from the continental populations and can have a unique gene pool that deserves conservation. Also, in Japan, B. ovalifolia is distributed only in Sarabetsu and Nishibetsu mires and deserves conservation as national resource. On the other hand, if there exists gene flow among Hokkaido and continental populations, effective conservation should be planned considering genetic connectivity with populations abroad. Population genetics of B. ovalifolia in northeast Asia for conservation is the topic of our future investigation.

\section{Acknowledgements}

We thank the staff of the Hokkaido prefecture, Betsukai town, and Sarabetsu village for sampling permission. This study was supported in part by Grants-in-Aid for Scientific Research, KAKENHI to K.N. (16K18596, 20K060870003) and a research grant from the Mitsui \& Co. Environment Fund to K.N. (R15-0067). 


\section{References}

Ashburner KB, McAllister HA (2016) The genus Betula: a taxonomic revision of birches (reprint with corrections). Kew Publishing, London, 432 pp.

Erikkson G, Jonsson A (1986) A review of the genetics of Betula. Scandinavian Journal of Forest Research 1(1-4): 421-434. https://doi.org/10.1080/02827588609382434

Gray SF (1996) Betula. In: Charkevicz SS (Ed.) Plantae Vasculare Orientis Extremi Sovietici 8. NAUK, Moscow, 13-24.

Hara H (1979) Comments on the East Asiatic plants 6. Shokubutsu Kenkyu Zasshi 54: 97105.

Hokkaido (2001) Hokkaido red list (plants). Hokkaido Government, Sapporo. http://www. pref.hokkaido.lg.jp/ks/skn/grp/03/redlist1.pdf [accessed 12.6.2020]

Ito K (1981) Alpine Plants in Hokkaido. Seibundo Shinkosha, Tokyo, 230 pp.

Kuzeneva OI (1985) Betula. In: Komarov VL (Ed.) Flora of the U. S. S. R. 5. NAUK, Moscow, 213-241. https://archive.org/stream/floraofussr05bota\#page/240/mode/2up/search/ betula [accessed 10.6.2020]

Li P, Skvortsov AK (1999) Betulaceae. In: Wu ZY, Raven PH (Eds) Flora of China 4. Science Press, Beijing, and Missouri Botanical Garden Press, St. Louis, 286-313.

Ministry of the Environment, Government of Japan (2020) Ministry of the Environment red list 2020. Ministry of the Environment, Government of Japan, Tokyo. https://www.env. go.jp/press/files/jp/113667.pdf [accessed 11.6.2020]

Murata G (1978) Taxonomical Notes 12. Acta Phytotaxonomica et Geobotanica 29: 95-105.

Murata G (1979) Betulaceae. In: Kitamura S, Murata G (Eds) Colored illustrations of herbaceous plants of Japan (Choripetalae). Hoikusha, Osaka, 284-304.

Nagamitsu T, Kawahara T, Hotta M (2004) Phenotypic variation and leaf fluctuating asymmetry in isolated populations of an endangered dwarf birch Betula ovalifolia in Hokkaido, Japan. Plant Species Biology 19(1): 13-21. https://doi.org/10.1111/j.1442-1984.2004.00097.x

Nemoto T (2016) Betulaceae. In: Ohashi H, Kadota Y, Murata J, Yonekura K, Yahara (Eds) Wild flowers of Japan II revised new edition. Heibonsha, Tokyo, 107-119.

Ohba H (2006) Betula L. In: Iwatsuki K, Boufford DE, Ohba H (Eds) Flora of Japan. Angiospermae, Dicotyledoneae, Archichlamydeae (a) vol IIa. Koudansha, Tokyo, 31-37.

Probatova NS, Sokolovskaya AP (1995) Chromosome numbers in some species of vascular plants from the Russian Far East. Botanicheskii Zhurnal 80: 85-88.

Tabata H (1966) A contribution to the biology of Japanese birches. Memories of the College of Science, University of Kyoto, Series B. Biology (Basel) 32: 239-271.

Takahashi H (2013) Report on the habitats of Betula tatewakiana in Betsukai-cho. In: Educational committee of Betsukai-cho (Eds) Report on the habitats of Betula tatewakiana in Nishibetsu mire, Natural monument of Hokkaido. Educational committee of Betsukaicho, Betsukai, 13-15.

Takahashi H (2015) Betula ovalifolia. In: Yahara T, Fujii S, Ito M, Ebihara A (Eds) Red data plants. Yama-kei Publishers, Tokyo, 212 pp.

Takahashi H, Oida K, Takahashi M, Yonaha T (2013) Betula tatewakiana habitats in Betsukai-cho. In: Educational committee of Betsukai-cho (Eds) Report on the habitat of Betula tatewakiana 
in Nishibetsu mire, Natural monument of Hokkaido. Educational committee of Betsukaicho, Betsukai, 5-12.

Wang N, McAllister HA, Bartlett PR, Buggs RJA (2016) Molecular phylogeny and genome size evolution of the genus Betula (Betulaceae). Annals of Botany 117(6): 1023-1035. https:// doi.org/10.1093/aob/mcw048

Watanabe S (1995) Betulaceae. In: Iwatsuki K, Ohba H, Shimizu T, Hotta M, Prance TG, Raven HP (Eds) Asahi encyclopedia. The world of plants 8, The Asahi Shimbun Tokyo, 98-119.

Watanabe S, Ohki M (1959) A new species of Betula from Hokkaido. Shokubutsu Kenkyu Zasshi 34: 329-332.

Watanabe S, Somego M (1991) Chromosome numbers of two species of subgenus Chamaebetu$l a$, genus Betula from Japan. In: Botanical Society of Japan (Ed.) Proceedings of the $56^{\text {th }}$ annual meeting of the Botanical Society of Japan. Botanical Society of Japan, Tokyo, 331 pp.

\section{Appendix I}

Specimens for morphological observation:

\section{Betula tatewakiana}

JAPAN, Hokkaido: Sarabetsu village, 18 August 1958, (H. Suzuki and M. Ohki, s.n., holotype, SAPS); Sarabetsu mire, 4237.33'N, $143^{\circ} 15.72^{\prime} \mathrm{E}$, alt. $166 \mathrm{~m}$, 5 June 2017, Yuki Shiotani 65-115 (51 specimens, SAPT); Nishibetsu mire, $43^{\circ} 23.36$ ' N, $145^{\circ} 03.66^{\prime} \mathrm{E}$, alt. $32 \mathrm{~m}$, 7 June 2017, Yuki Shiotani 1-26, 31-49 (45 specimens, SAPT)

\section{B. ovalifolia}

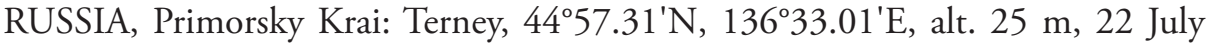
2016, Koh Nakamura 14169-14195, 14197, 14198 (29 specimens, SAPT); Terney, $44^{\circ} 56.85^{\prime} \mathrm{N}, 136^{\circ} 33.00^{\prime} \mathrm{E}$, alt. 9 m, 23 July 2016, Koh Nakamura 14289_ 14297 (9 specimens, SAPT) 